Original Article

\title{
Reliability and validity of the Exercise Benefits/Barriers scale in the elderly*
}

\author{
Confiabilidade e validade da Exercise Benefits/Barriers scale em idosos \\ Confiabilidady validez de la Exercise Benefits/Barriers Scale en ancianos
}

Janaína Fonseca Victor ${ }^{1}$, Lorena Barbosa Ximenes ${ }^{2}$, Paulo César de Almeida ${ }^{3}$

\begin{abstract}
Objective: Assess the reliability and validity of the Exercise Benefits/Barriers Scale (EBBS) in the elderly. Methods: The reliability was assessed by internal consistency (Cronbach's alpha) and by the test-retest Kendall's W. To verify the construct validity it was used a correlation between the EBBS results and the personal and clinic variables. Results: The Cronbach's alfa of the EBBS was 0.94. The test-retest value was 0.60. The variables that presented association with the EBBS were: level of education $(p=0.02)$, practice of physical activity $(p=0.0001)$, with whom one resides $(p=0.032)$ and lifestyle $(p=0.0001)$. Conclusion: The statistical analysis revealed that the translated version of the EBBS is valid and reliable however, its use is recommended in different scenarios due to regional differences in Brazil, in order to have the validity of the instrument widely exploited.
\end{abstract}

Keywords: Validation studies; Health of the elderly; Motor activity.

\section{RESUMO}

Objetivo: Avaliar a confiabilidade e validade da Exercise Benefits/ Barriers Scale (EBBS) em idosos. Métodos: A confiabilidade foi avaliada por meio da consistência interna (alfa de Cronbach) e pelo teste-reteste w de kendall, para a verificação da validade de construto utilizou-se a correlação entre os resultados da EBBS e as variáveis pessoais e clínicas. Resultados: O Alfa de Cronbach da EBBS foi de 0,94. O valor do teste-reteste foi 0,60 . As variáveis que apresentaram associação com a EBBS foram: escolaridade $(p=0,02)$, prática de atividade física $(p=0.0001)$, com quem reside $(p=0,032)$ e estilo de vida $(p=0,0001)$. Conclusão: A análise estatística revelou que a versão traduzida da EBBS é confiável e válida, todavia recomenda-se a sua utilização em outros cenários, devido as diferenças regionais do Brasil, para que a validade do instrumento seja amplamente explorada.

Descritores: Estudos de validação; Saúde do idoso; Atividade motora

\section{RESUMEN}

Objetivo: Evaluar la confiabilidad y validez de la Exercise Benefits/Barriers Scale (EBBS) en ancianos. Métodos: La confiabilidad fue evaluada por medio de la consistencia interna (alfa de Cronbach) y por el test-retest w de kendall, para la verificación de la validez de constructo se utilizó la correlación entre los resultados de la EBBS y las variables personales y clínicas. Resultados: El Alfa de Cronbach de la EBBS fue de 0,94. El valor del test-retest fue de 0,60. Las variables que presentaron asociación con la EBBS fueron: escolaridad ( $\mathrm{p}=0,02)$, práctica de actividad física $(\mathrm{p}=0.0001)$, con quien reside $(\mathrm{p}=0,032)$ y estilo de vida $(\mathrm{p}=0,0001)$. Conclusión: El análisis estadístico reveló que la versión traducida de la EBBS es confiable y válida, recomendándose su utilización en otros escenarios, debido a las diferencias regionales del Brasil, para que la validez del instrumento sea ampliamente explotada.

Descriptores: Estudios de validación; Salud del anciano; Actividad motora

\footnotetext{
* Study extracted from the thesis of Doctorate "Translation and validation of the Exercise Benefits/Barriers Scale: application in the elderly" presented to the Nursing Post Graduation Program of the Federal University of Ceará. UFC. Fortaleza. Ceará. Brazil.

${ }^{1}$ PhD in Nursing. Professor at the Faculty of Pharmacy, Dentistry and Nursing, Federal University of Ceará - UFC - Fortaleza (CE), Brazil.

${ }^{2}$ PhD in Nursing. Professor at the Faculty of Pharmacy, Dentistry and Nursing, Federal University of Ceará - UFC - Fortaleza (CE), Brazil.

${ }^{3} \mathrm{PbD}$ in Statistics. Professor at the State University of Ceará - UFC - Fortaleza (CE), Brazil.
} 


\section{INTRODUCTION}

The practice of physical activity or physical exercise can be determined both by the comprehension of a person about the benefits it can bring, as well as by the negative aspects, also perceived as barriers ${ }^{(1,2)}$.

The perception of benefits is constituted of positive mental representations that involve factors which reinforce, facilitate, nurture and enable the adoption of a behavior. The benefits can be intrinsic (improving health, feelings of well-being) or extrinsic (social interaction, financial reward). A positive perception towards physical activity may encourage people to develop it $^{(1,3)}$.

The barriers though, consist on obstacles, inconveniences, difficulties and expenses, and may be real or imaginary. The perception of barriers is a component that influences decisions regarding behavior ${ }^{(1)}$. In the elderly particularly, the barriers that permeate their engagement in physical activity involve: fear of falling or injury, of being victim of violence when exercising outdoors, fatigue, morbidity, physical limitation, pain and also lack of companionship, of time and of family encouragement ${ }^{(4-6)}$.

The identification of barriers and the adequate comprehension of the benefits of physical activity do not necessarily lead to the adoption of a physically active lifestyle. However, without proper knowledge and perception on the subject it is not likely that changes will occur in the pattern of behavior. Researches show that in more vulnerable populations, when their beliefs about physical activity are known, the interventions are more effective ${ }^{(7)}$.

It is relevant to clarify that the expressions physical activity and physical exercise are not synonyms. Although aware of the differences of the expressions, in this study it is a consensus that physical activity is a bodily movement produced by the skeletal muscles which results in energy expenditure, having components and determinants of biological, psychosocial, cultural and behavioral order that can be exemplified by games, dance, sports and physical exercise ${ }^{(8,9)}$.

Many scholars make efforts to understand the prevalence, the difficulties and facilities for adherence and maintenance of physical activity practice in the population, especially in the application of instruments capable of identifying the related factors that interfere in this practice $^{(5,6)}$.Thus, the use of instruments should offer a measurement that is objective and psychometrically precise. In the absence of national instruments, the use of equipment developed in other cultures is recommended as long as they follow judicious methods in the transcultural adaptation ${ }^{(10)}$. This procedure reduces costs on the elaboration of new instruments and provides results that can be compared and discussed.

In international literature is found the Exercise Benefits/Barriers Scale(EBBS) ${ }^{(11)}$, an instrument of psychometric evaluation capable of identifying the perception of barriers and benefits for the practice of exercise and thus able to recognize the factors that interfere in this practice. It has been widely used by American, European and Asian researchers ${ }^{(12-14)}$.

The EBBS was prepared based on the Health Promotion Model (HPM), which assesses the activities focused on the development of resources which maintain or intensify the well-being, for example, the physical activity. The HPM considers the actions of health promotion by the interrelation of three components: individual characteristics, feelings and knowledge about the behavior to be achieved and the desirable health behavior. This model has been developed by Dr Nola J Pender, Professor Emerita of the School of Nursing, University of Michigan - United States of America.

The EBBS has been translated and adapted for use in Brazil for application on the elderly ${ }^{(12)}$ therefore its psychometric properties shall be assessed.

\section{OBJECTIVE}

The objective is to evaluate the reliability and validity of the Exercise Benefits/Barriers Scale on the elderly.

\section{METHODS}

It is a methodological study of validation of the EBBS psychometric properties. The population studied was composed of elderly people treated at a Basic Unit of Family Health in the city of Fortaleza, state of Ceará, between January and December, 2009. The sample was formed by 214 elderlies and calculated based on the formula for a finite population.

The criteria established for inclusion in the study were: to be aged 60 or over, not to have dementia or any kind of alteration resulting on impairment to verbal communication. The criterion for exclusion was to have looked for the Health Unit for consultations of clinical emergency, of physical or psychological discomfort.

The adapted version of the EBBS is consisted of 42 items, 14 of the Barriers Scale and 28 of the Benefits Scale. This scale presents answer options of the Likert type with rating levels varying from one (1) to four (4): strongly agree (4), agree (3), disagree (2), strongly disagree (1). When used together, the EBBS has a reverse score of the items of the Barriers Scale, ranging from 42 until 168. Isolatedly, the highest score is of the Benefits Scales that ranges from 28 to 112 and of the Barriers Scale, from 14 until 56 , representing the best perception of the benefits and the barriers respectively.

The form to characterize the subjects consisted of socio-demographic, clinical, anthropometric, physiological, biochemical, lifestyle, morbidity and injury (occurrence of falls) variables. 
The homogeneity of the instrument was assessed by Cronbach's Alpha separately for the total scale, the Benefits and the Barriers scale. For the items quality analysis the coefficient of Cronbach's alpha was used with the item suppressed.

The stability was calculated using the test-retest by Kendall's coefficient of concordance or Kendall W. It was chosen for not making assumptions about the nature of probability distribution as well as being able to handle any number of distinct results thus, more adequate to the characteristics of the instrument. For the test-retest performance the first 35 participants of the study were asked to return after four weeks, occasion in which the EBBS was reapplied.

The validity related to the construct was analyzed through the investigation of associations among the EBBS results and the evaluation of personal and clinical aspects that, according to literature, are capable of interference in the knowledge of the benefits and realization of the physical exercise ${ }^{(12,14,15)}$ aiming to detect the interference of these on the EBBS result. The variables investigated were: socio-demographic (age, level of education, marital status, occupation, with whom one lives and income), anthropometric and physiological (weight, height, BMI - Body Mass Index, blood pressure), biochemical (random glucose level), lifestyle (active, sedentary, regular physical activity practice, smoking, alcohol consumption, limitations for mobility), morbidities (chronic degenerative pathologies) and falls. The Fisher-Freeman Halton test was applied and the significance level fixed was $5 \%$.

The elderly who went to the Health Unit were invited to participate of the survey and guided to a private room for applying the translated version of the EBBS and the form through a structured interview. Next, the weight procedures and height measurements were carried out, as well as the verification of blood pressure and capillary glucose levels.

The data were collected by two nurses and two nursing academics, all properly trained.

The research project was approved by the ethics Committee of the Federal University of Ceará under number 15.706. The participants signed a Term of Consent contemplating the ethical aspects contained in the Resolution 196/96 of the National Council of Health/ Ministry of Health.

\section{RESULTS}

The study participants were composed of $77.1 \%$ of females, had an average age of 68 years, $51.9 \%$ were illiterate, $49.5 \%$ were married, $48.9 \%$ received between 0.7 to 1 minimum wage monthly, $44.9 \%$ lived with their spouses, children and grandchildren, $85 \%$ suffered from chronic diseases, $37.4 \%$ were overweight, $32.2 \%$ were obese, $95.4 \%$ wandered without assistance, $84.6 \%$ reported an active lifestyle, 58\% practiced physical activity and 53.3\% had suffered falls during the last year.

Regarding the scale, the Cronbach's alpha total result was 0.94 when analyzed separately. The Cronbach's alpha for the Benefits Scale had a score of 0.93 and for the Barriers Scale it was 0.87. Additionally, these coefficients were estimated by observing the variation after the exclusion of each item of the scale (Tables 1 and 2).

Table 1. Values of the Cronbach's alpha coefficient with items deleted, Benefits Scale. Fortaleza, CE, Brazil, 2011.

\begin{tabular}{cc}
\hline Alpha \\
Detail Detail Description & $\begin{array}{c}\text { ached } \\
\text { by } \\
\text { deleting } \\
\text { the detail }\end{array}$ \\
\hline
\end{tabular}

01 I enjoy physical activity

0,91

02 Physical activity practice decreases my feelings of stress and tension

03 Physical exercise practice improves my mental health (feeling emotionally well ad happy)

0,90

05 I will prevent a heart attack by practicing physical activity

0,91

Physical activity practice improves my muscle

07 strengh (ability to employ an effort - eg push furniture, lift an object)

08 Physical activity gives me a feeling of personal accomplishment (feeling good about myself)

10 Physical activity practice makes me feel relaxed

11 Physical activity practice facilitates contact with friends and people I like having high blood pressure

Physical activity practice increases my level

15 of physical fitness (motor skills, capacity and ability to walk, climb stairs, sweep the house)

Physical activity practice improves the muscle

17 tone (muscles prepared for a movement of contraction)

18 Physical activity practice improves the functioning of the heart and blood vessels

0,92 I can improve my feelings of well-being (be happier) with physical activity practice

Physical activity practice improves the

22 flexibility (ability to perform movements with the joints, lift the arm, bend the body)

Physical activity practice increases everyday disposition (energy to do things)

0,91

Physical activity practice helps to sleep better at night

0,90

Physical activity practice reduces muscle fatigue

Physical activity practice is a good way to meet new people

Physical activity practice improves physical

30 endurance (being able to walk for 30 minutes or more) 


\begin{tabular}{|c|c|c|}
\hline Detail & Detail Description & $\begin{array}{c}\text { Alpha } \\
\text { achieved } \\
\text { by } \\
\text { deleting } \\
\text { the detail }\end{array}$ \\
\hline 31 & $\begin{array}{l}\text { Physical activity practice improves self-esteem } \\
\text { (the image I have of myself) }\end{array}$ & 0,91 \\
\hline 33 & $\begin{array}{l}\text { Physical activity practice improves mental } \\
\text { agility (speed of thought) }\end{array}$ & 0,92 \\
\hline 34 & $\begin{array}{l}\text { Physical activity practice allows the performance } \\
\text { of everyday tasks without feeling tired }\end{array}$ & 0.93 \\
\hline 35 & $\begin{array}{l}\text { Physical activity practice improves the quality } \\
\text { of the activities that I perform }\end{array}$ & 0,92 \\
\hline 37 & $\begin{array}{l}\text { Physical activity practice is a good } \\
\text { entertainment }\end{array}$ & 0,91 \\
\hline 38 & $\begin{array}{l}\text { Physical activity practice increases my } \\
\text { acceptance by others }\end{array}$ & 0,92 \\
\hline 39 & $\begin{array}{l}\text { Physical activity practice improves overall } \\
\text { body functioning }\end{array}$ & 0,92 \\
\hline 42 & $\begin{array}{l}\text { Physical activity practice improves the way my } \\
\text { body looks }\end{array}$ & 0,90 \\
\hline
\end{tabular}

Table 2. Values of the Cronbach's alpha coefficient with the items deleted, Barriers Scale. Fortaleza, CE, Brazil, 2011.

\begin{tabular}{|c|c|c|}
\hline Detail & Detail Description & $\begin{array}{c}\text { Alpha } \\
\text { achieved } \\
\text { by deleting } \\
\text { the detail }\end{array}$ \\
\hline 04 & Exercising takes too much of my time & 0,84 \\
\hline 06 & Physical activity practice causes fatigue & 0,86 \\
\hline 09 & $\begin{array}{l}\text { The places for physical activity practice are } \\
\text { too far away }\end{array}$ & 0,87 \\
\hline 12 & $\begin{array}{l}\text { I feel embarrassed to practice physical } \\
\text { activity }\end{array}$ & 0,86 \\
\hline 14 & Physical activity practice is costly & 0,85 \\
\hline 16 & $\begin{array}{l}\text { I do not have a convenient schedule for } \\
\text { physical activity practice }\end{array}$ & 0,85 \\
\hline 19 & Practicing physical activity tires me & 0,86 \\
\hline 21 & $\begin{array}{l}\text { My spouse (or significant other) does not } \\
\text { encourage physical activity practice }\end{array}$ & 0,87 \\
\hline 23 & $\begin{array}{l}\text { Physical activity practice takes too much } \\
\text { time from family relationships }\end{array}$ & 0,85 \\
\hline 27 & $\begin{array}{l}\text { I think clothes for physical activity practice } \\
\text { show too much of the body }\end{array}$ & 0,86 \\
\hline 32 & $\begin{array}{l}\text { My family members do not encourage me to } \\
\text { practice physical activity }\end{array}$ & 0,86 \\
\hline 36 & $\begin{array}{l}\text { Physical activity takes too much time from } \\
\text { family responsibilities }\end{array}$ & 0,85 \\
\hline 39 & Physical activity practice is a difficult task & 0,85 \\
\hline 41 & $\begin{array}{l}\text { There are few places for physical activity } \\
\text { practice }\end{array}$ & 0,87 \\
\hline
\end{tabular}

The value of the test-retest of the EBBS calculated by Kendall's concordance coefficient was 0.60 (p 0.0001).

When it comes to the construct validity, the investigation of the association of the elderly characteristics with the Benefits Scale had associations with the variables level of education $(p=0.02)$ and physical activity practice $(p=0.0001)$. The other variables investigated revealed no influence over the scale results.

Regarding the Barriers Scale, there was association with the variables level of education $(p=0.0001)$, with whom one resides $(p=0.032)$ and lifestyle $(p=0.0001)$. Just as with the Benefits Scale, there was no statistically significant association with the clinical, anthropometric and biochemical variables.

\section{DISCUSSION}

The results of reliability by Cronbach's alpha revealed values close to one, showing this is a reliable measure. The values found indicated another positive aspect as they were really close to those of the original instrument, both in the total scale (0.95) and in the Benefits Scale and Barries Scale (0.95 and 0.86 respectively). Alpha values are considered acceptable when between 0.70 and $0.90^{(11,16)}$. It is worth to note that the minimum value an item should have to consistently measure the same construct is 0.70 . In the behavior analysis of each item in relation to its contribution to the internal consistency of the instrument, there was minimal variation of the alpha values, an indicator that the individual items of the translated version are congruent or complementary ${ }^{(17)}$.

The analysis of the EBBS stability revealed a value considered adequate however lower than the original instrument one, which is 0.89 . The Kendall $\mathrm{W}$ values increase with the level of agreement, varying between zero ( 0 - without consensus) and one ( 1 - perfect consensus), values around 0.7 indicate strong agreement ${ }^{(18)}$. There was excellent statistical significance $(p=0.0001)$ which allows to affirm that the odds of this agreement to have happened purely by chance is only one in 10 000. It is worth to mention that when faced with many variables it is difficult to obtain high values of W because the EBBS has 42 items with four options of response ${ }^{(18)}$.

It is also noteworthy that on several times the original and the adapted instruments find no similar values when having their psychometric properties confronted, which does not mean that the translated version cannot be considered adequate ${ }^{(19)}$.

In this research the relevant points in the investigation of the EBBS validation were: the association between the variables level of education and physical activity practice with the Benefits Scale. The level of 
education influenced the perception of the physical activity benefits showing that the scale was sensitive to capture this difference, once the level of education has great influence regarding the physical activity practice and the knowledge of its benefits ${ }^{(20,21)}$.

In this sense, the association between the practice of physical activity with the Benefits Scale is an indicator that the scale is an instrument capable of measuring the perception of the physical activity benefits on the elderly, as people who practice physical activities are more sensitive to perceive its benefits, when compared with those who do not practice ${ }^{(3,22)}$.

Another relevant aspect was the association between the Barriers Scale and the variables level of education, lifestyle and with whom one resides, since literature points that the socioeconomic, demographic, behavioral and environmental characteristics influence on the level of knowledge, on the adherence and consequently, on the attitudes and beliefs about physical activity ${ }^{(2,23,24)}$.

In this study the most prevalent family arrangement was the co-residence of the elderly with their children and grandchildren, culturally frequent in $\mathrm{Brazil}^{(24)}$. The multigenerational domicile may represent a barrier for the practice of physical activity, as many elderly people assume the role of caring for the grandchildren, a factor that limits the time for other activities ${ }^{(25,26)}$.

Given the above, it can be argued that a limitation of this study is the non-occurrence of associations between the EBBS and the variables income and gender. Researches show that these variables are directly related to higher levels of physical activity and consequently, with a better perception of its benefits ${ }^{(26-28)}$. This finding reinforces the need for new surveys with a larger number of elderlies in order to refute or confirm these associations, since several researches about physical activity study adults and elderly together and this might influence the results ${ }^{(12-29)}$.

Regarding the non-influence of the elderly clinical variables on the EBBS results, it is unlikely to discuss if the data resembled or differed from other researches,

\section{REFERENCES}

1. Pender NJ, Murdaugh CL, Parsons MA. Health promotion in nursing practice. 4th ed. Upper Saddle River (NJ): Prentice Hall; 2002.

2. Silva SG, Silva MC, Nahas MV, Viana SL. [Variables associated with leisure-time physical inactivity and main barriers to exercise among industrial workers in Southern Brazil]. Cad Saúde Pública. 2011;27(2):249-59. Portuguese.

3. Cardoso AS, Borges LJ, Mazo GZ, Benedetti TB, Kuhnen AP. Fatores influentes na desistência de idosos em um programa de exercício físico. Movimento (Porto Alegre). 2008;14(1):225-39.

4. Schutzer KA, Graves BS. Barriers and motivations to exercise in older adults. Prev Med. 2004;39(5):1056-61.

5. Cassou AC, Fermino RC, Santos MS, Rodriguez-Añez CR, as studies of this nature are complex and rare in the literature $^{(21-28)}$, thus making it impossible to compare the data with previous studies. But this fact and the others here presented made accessible a universe of possibilities for future research on the topic. Another additional aspect that should be investigated with the EBBS refers to the availability of community resources that facilitate or constrain physical activity because studies on the topic elucidate the association between the presence of these features and positive encouragement for physical activity ${ }^{(23,30,31)}$.

In order to continue the assessment process of the psychometric properties of the EBBS, it is relevant that it is applied on other research scenarios due to the regional differences in Brazil, so that the validity of the instrument is widely exploited.

\section{CONCLUSION}

The study has reached the objective proposed regarding the analysis of the reliability and the validity of the EBBS for the elderly. The statistical analysis revealed that the translated version of the EBBS is reliable. The validity of the analized construct when using personal and clinic parameters found a satisfactory correlation with the variables level of education and physical activity practice, and the Benefits Scale. The Barriers Scale presented correlation with the level of education, the lifestyle and with whom one resides. These findings make it possible to recommend the use of the EBBS to assess the perception of benefits and barriers to the practice of physical activity however, it is necessary the accession of new researchers to increase the methodological development of the EBBS in the Brazilian context.

\section{THANKS}

Thank you to the Fundação Cearense de Apoio ao Desenvolvimento Científico e Tecnológico - FUNCAP (Foundation to Support Scientific and Technological Development).
Reis RS. Barreiras para a atividade física em idosos: uma análise por grupos focais. Rev Educ Fís. 2008;19(3):353-60.

6. Zaitune MP, Barros MB, César CL, Carandina L, Goldbaum M, Alves MC. [Factors associated with global and leisure-time physical activity in the elderly: a health survey in São Paulo (ISASP), Brazil]. Cad Saúde Pública. 2010;26(8):1606-18. Portuguese.

7. Schoenfelder DP, Rubestein LM. An exercise program to improve fall-related outcomes in elderly nursing home residents. Appl Nurs Res. 2004;17(1):21-31.

8. Pitanga FJ, Lessa I. [Prevalence and variables associated with leisure-time sedentary lifestyle in adults]. Cad Saúde Pública. 2005;21(3):870-7. Portuguese.

9. Victor JF, Ximenes LB, Almeida PC. [Cross-cultural adaptation of the Exercise Benefits/Barriers Scale (EBBS) 
for application in elderly Brazilians: preliminary version]. Cad Saúde Pública. 2008;24(12):2852-60. Portuguese.

10. Cruciani F, Adami F, Assunção NA, Bergamaschi DP. [Conceptual, item, and semantic equivalence of a Brazilian version of the Physical Activity Checklist Interview (PACI)]. Cad Saúde Pública. 2011;27(1):19-34. Portuguese.

11. Sechrist KR, Walker SN, Pender NJ. Development and psychometric evaluation of the exercise benefits/barriers scale. Res Nurs Health. 1987;10(6):357-65.

12. Fahrenwald NL, Walker SN. Application of the Transtheoretical Model of behavior change to the physical activity behavior of WIC mothers. Public Health Nurs. 2003;20(4):307-17.

13. Hwang EH, Chung YS. [Effects of the exercise self-efficacy and exercise benefits/barriers on doing regular exercise of the elderly]. Taehan Kanho Hakhoe Chi. 2008;38(3):428-36. Korean

14. Lovell GP, El Ansari W, Parker JK. Perceived exercise benefits and barriers of non-exercising female university students in the united kingdom. Int J Environ Res Public Health. 2010; 7(3):784-98.

15. Ohsiek S, Williams M. Psychological factors influencing weight loss maintenance: an integrative literature review. J Am Acad Nurse Pract. 2011;23(11):592-601.

16. Pasquali L. Psicometria: teoria e aplicações. Brasília: Universidade de Brasília; 1997.

17. Rowland D, Arkkelin D, Crisler L. Computer-based data analysis using SPSS in the social and behavioral sciences. Chicago: Nelson-Hall; 1991.

18. Schmidt RC. Managing delphi surveys using nonparametric statistical techniques. Dec Sci. 1997;28(3):763-74.

19. Mello MF, Schoedl AF, Pupo MC, Souza AA, Andreoli SB, Bressan RA et al. [Early Trauma Inventory (ETI): crosscultural adaptation and internal consistency]. Cad Saúde Pública. 2010;26(4):713-24. Portuguese.

20. Phillips EM, Scheneider JC, Mecer GR. Motivating elderls to initiate and maintain exercise. Arch Phys Med Rehabil. 2004;85(7 Suppl 3):S52-7.

21. Siqueira FV, Facchini LA, Piccini RX, Tomasi E, Thumé E, Silveira DS, et al. PPhysical activity in young adults and the elderly in areas covered by primary health care units in municipalities in the South and Northeast of Brazil]. Cad Saúde Pública. 2008;24(1):39-54. Portuguese.

22. Caromano FA, Ide MR, Kerbauy RR. [Exercise maintenance among older adults]. Rev Dep Psicol UFF. 2006;18(2):177-92. Portuguese.

23. van Stralen MM, de Vries H, Mudde AN, Bolman C, Lechner L. The working mechanisms of an environmentally tailored physical activity intervention for older adults: a randomized controlled trial. Int J Behav Nutr Phys Act [Internet]. 2009 [cited 2010 Oct 21]; 6:83. Available from: http://www.ijbnpa. org/content/pdf/1479-5868-6-83.pdf

24. Salvador EP, Reis RS, Florindo AA. Practice of walking and its association with perceived environment among elderly Brazilians living in a region of low socioeconomic level. Int J Behav Nutr Phys Act [Internet]. 2010 [cited 2010 Oct 13]; 7:67. Available from:http://www.ijbnpa.org/content/ pdf/1479-5868-7-67.pdf

25. Santos SR, Santos IB, Fernandes MG, Henriques ME. [Quality of life ofthe elderly in the community: application of the Flanagan scale]. Rev Latinoam Enferm. 2002;10(6):757-64.

26. Pavarini SC, Luchesi BM, Fernandes HC, Mendiondo MS, Filizola CL, Barham EJ, et al. Genograma: avaliando a estrutura familiar de idosos de uma unidade de saúde da família. Rev Eletr Enf [Internet]. 2008 [citado2010 Nov 13]; 10(1):39-50 Disponível em: http:/ /www.fen.ufg.br/revista/ v10/n1/pdf/v10n1a04.pdf

27. Harrison RA, Mcelduff P, Edwards R. Planning to win: health and lifestyles associated with physical activity amongst 15,423 adults. Public Heath. 2006;120(3):206-12.

28. Alves JG, Siqueira FV, Figueiroa JN, Facchini LA, Silveira DS, Piccini RX, et al. [Physical inactivity among adults and elderly living in areas covered by primary healthcare units with and without the Family Health Program in Pernambuco State, Brazil]. Cad Saúde Pública. 2010;26(3):543-56. Portuguese

29. Heesch KC, van Uffelen JG, Hill RL, Brown WJ. What do IPAQ questions mean to older adults? Lessons from cognitive interviews. Int J Behav Nutr Phys Act [Internet]. 2010 [cited 2010 Nov 13]; 7:35. Available from: http:/ /www. biomedcentral.com/content/pdf/1479-5868-7-35.pdf

30. Warburton DE, Charlesworth S, Ivey A, Nettlefold L, Bredin SS. A systematic review of the evidence for Canada's Physical Activity Guidelines for Adults. Int J Behav Nutr Phys Act [Internet]. 2010 [cited 2010 Nov 13]; 7:39. Available from: http://www.ijbnpa.org/content/pdf/1479-5868-7-39.pdf

31. Victor JF, Ximenes LB, Almeida PC, Vasconcelos FF. Sociodemographic and clinical profile of elders who receive Care in a Family Health Unit. Acta Paul Enferm. 2009;22(1):49-54. 